International Journal of Applied Engineering Research

ISSN 0973-4562 Volume 9, Number 13 (2014) pp. 2241-2249

(C) Research India Publications

https://dx.doi.org/10.37622/IJAER/9.13.2014.2241-2249

\title{
Effect of Aluminum Content on Microstructure and Corrosion Behavior of as Cast Fe-Al-C Alloys Lightweight Steel
}

\author{
Ratna Kartikasari \\ Department of Mechanical Engineering, \\ "Nasional" College of Technology, Jl. Babarsari No. 1, \\ CT, Yogyakarta, Indonesia 55281
}

\begin{abstract}
Effects of aluminum content on microstructure and corrosion behavior of as cast Fe-Al-C alloys lightweight steel have been studied. The alloys were prepared by an induction furnace under an argon atmosphere. Microstructure of Fe-Al-C alloys containing 1.24, 3.3, 5.5, 7.5, and 9.05 wt-\% aluminum showed ferrite and pearlite, where the higher levels of $\mathrm{Al}$ increases the amount of ferrite structures. Scanning electron microscope test results indicate the presence of aluminum carbides at the grain boundary of pearlite of Fe-Al-C alloy with $3.3 \%$ up to $9.05 \% \mathrm{Al}$. At $9.05 \% \mathrm{Al}$ alloy structure nearly $100 \%$ ferrite, pearlite structures remaining are in the ferrite grain boundaries. An increase $\mathrm{Al}$ content resulted in significant improvement corrosion resistance in $0.5 \% \mathrm{NaCl}$ solution.
\end{abstract}

Keyword: Fe-Al-C alloys, argon atmosphere, microstructure, corrosion resistance

\section{Introduction}

The steel is still ranked as the top (90\%) material in the world until now [1]. The impact of the world energy crisis demands technological innovation on all fronts for the discovery of new energy sources and efficient use of energy. In the field of materials, innovation focused on the invention of development of materials that support of energy savings. Development of lightweight Steel is the research focus of the world steel practitioners. An experiment of steel alloyed with light metals is one of the efforts to achieve the target of lowering the density of steel. 
Adding a large amount of light elements such as aluminum to steels is not a new concept recalling that several Fe-Al-Mn-C alloys were patented in 1950s for replacement of nickel or chromium in corrosion resistance steels. However, the socalled lightweight steels or low-density steels were revisited recently, which is driven by demands from the industry where steel has served as a major structural material. Strengthening without loss of ductility has been a triumph in steel research, but lowering the density of steel by mixing with light elements will be another prospect that may support the competitiveness against emerging alternatives such as magnesium alloys. In this paper, we review recent studies on lightweight steels, emphasizing the concept of alloy design for microstructures and mechanical properties [2].

Newly developed lightweight steel based on ferritic iron aluminum or austeniticmanganese aluminum are showing promising physical, mechanical, and technological properties, such as high specific elastic stiffness and strength, excellent ductility and formability, reduced specific weight, and an improved corrosion resistance as well[3].

It has been developed that Fe-Al-C alloy is a good candidate for replacing some of the conventional stainless steel in several applications at moderate to high temperature [4]. Wherein, $\mathrm{Al}$ is used to substitute expensive alloy elements in conventional $\mathrm{Fe}-\mathrm{Cr}$ $\mathrm{C}$ system. Ferritic iron aluminum alloys shows promising physical and mechanical properties along with superior corrosion and oxidation resistance at much lower raw material cost [5]. Therefore it is suitable for development of new type of high strength lightweight steel [3]. Besides these the plain iron-aluminum steel containing up to 9 wt- $\%$ Al has substantially lower density of at least $10 \%$.

$\mathrm{Fe}-\mathrm{Al}$ alloys exhibit poor toughness. These are brittle at room temperature [6]. Addition of carbon to $\mathrm{Fe}-\mathrm{Al}$ containing 8.5 to $16 \mathrm{wt}-\% \mathrm{Al}$ gives higher strength [7], and better machinability [8]. It has been shown that low carbon content $(0.5$ and 0.1 wt- $\%$ ) in Fe-9 wt-\% Al leads to low tensile ductility. Whereas, the ESR (Electro Slag Refined) ingots of $\mathrm{Fe}-10.5 \mathrm{Al}$ and $\mathrm{Fe}-13 \mathrm{Al}$ alloys containing high $(0.5$ and $1.0 \mathrm{wt}-\%)$ carbon exhibit excellent hot workability [9]. Fe-Al-C alloy is being developed for elevated temperature structural application up to $873 \mathrm{~K}$ [10].

Aluminum plays a major role in the oxidation and corrosion resistance which is characteristic of the binary Fe-Al alloy [11]. The Fe-Al-C alloys have good corrosion resistance in a neutral environment. Its corrosion rates are comparable to that of white cast-iron in acid environments [12]. However, few data are available on the corrosion phenomena of Fe-Al alloy in low concentration acid media. The aims of this research are to evaluate the effect of aluminum content on microstructure and corrosion behavior of as cast Fe-Al-C alloys lightweight steel.

\section{Experiment Procedure}

Thirty five kilograms of Fe-Al-C was prepared from mild steel scrap, high purity aluminum, and $\mathrm{Fe}-\mathrm{C}$. The alloy was prepared in an induction furnace under argon atmosphere. The chemical compositions are listed in table 1 . The ingot was cut using bimetallic band saw blade to make specimens for microstructure $(14 \mathrm{~mm}$ in gauge diameter and $10 \mathrm{~mm}$ in gauge length) and corrosion (14 $\mathrm{mm}$ in gauge diameter and 3 
$\mathrm{mm}$ in gauge length) studies. The microstructure specimens were examined by optical and electron microscope. The phases present in the specimens were identified byX-ray diffraction technique. A copper target with nickel filter and graphite single crystal monochrometer was used to record the diffraction pattern.

The surface of the corrosion specimens were mechanically polished with abrasive paper up to 1200 grit, after surface finishing. The last mechanical polishing was done with $0.5 \mu \mathrm{m}$ alumina paste. The corrosion measurements were carried out with threeelectrode polarization in $0.5 \% \mathrm{NaCl}$. The corrosion type and the morphology of the oxide scale were determined by optical and scanning electron microscope (SEM). Corrosions products were examined using EDS/EDAX.

The polished section were subsequently etched with $3.3 \%$ HNO3-3.3\% $\mathrm{CH} 3 \mathrm{COOH}-0.1 \% \mathrm{HF}-93.3 \% \mathrm{H} 2 \mathrm{O}$ by volume for micro structural examination by optical microscope.

\section{Result and Discussion Microstructure}

Figure 1 shows the optical microstructures of the cast alloys. The as cast alloys are composed of ferrite and pearlite at all level $\mathrm{Al}$, where higher level of $\mathrm{Al}$ increases the amount of ferrite phases but decreases the amount of pearlite phases. At the $\mathrm{Al}$ content of $9.05 \%$ is a low pearlite phases remains only in the area along the grain boundaries. This proved the role of $\mathrm{Al}$ as a ferrite stabilizer in the Fe-Al-C alloy so that the higher levels of $\mathrm{Al}$ will be the more ferrite structures are formed. Based on the phase diagram of $\mathrm{Fe}-\mathrm{Al}$ [13] up to $10 \mathrm{wt} \% \mathrm{Al}$ content the stable phase is ferrite. The presence of carbon a fairly high $(0.6 \mathrm{wt}-\%)$ led to appearance pearlite phase is quite dominated, especially at levels up to $7.5 \% \mathrm{Al}$. The $\mathrm{Al}$ atoms (atomic radius of 1.82 A), in the system of $\mathrm{Fe}$ will take a position as a solid solution substitution, due to atomic radius of $\mathrm{Al}$ is greater than the atomic radius of $\mathrm{Fe}-\mathrm{Al}$ phase diagram [3]. On the iron rich side, three types of b.c.c lattice structures are present. These are the non ordered A2 lattice which occurs in the iron-aluminum solid solution up to about 20 at$\% \mathrm{Al}(10 \mathrm{wt}-\% \mathrm{Al})$ at room and high temperatures. Here the iron and aluminum atoms are statistically distribute in the lattice.

Figure 1a shows presence of ferrite and pearlite grains are tend to form equiaxed. As seen figure $1 \mathrm{~b}, \mathrm{c}, \mathrm{d}$ and e, dendrite structure more clearly looked; this is due the nucleation of $\mathrm{Al}$ carbide which has dendritic pattern [14]. The higher levels of $\mathrm{Al}$ dendrite structure decreases and dominated by the ferrite structure. Up to Al content $9.05 \%$ ferrite crystal structure has not been reached perfect. Fe-Al alloy-C will be have the perfect ferrite structure at content $\mathrm{Al} \mathrm{12 \%}$, the phase will be a $100 \%$ alloy ferritic on $\mathrm{Al}$ content above $10 \%$ [9].

Figure 2 shows SEM images of the Fe-Al-C alloy FeAl is seen that the precipitate is white and uniformly distributed. This precipitate has a BCC atoms structure [9]. Intermetallic compounds of FeAl have the BCC structure (A2) to Al content $10 \mathrm{wt}-$ $10 \%$ [3]. The higher levels of $\mathrm{Al}$ tendency $\mathrm{FeAl}$ intermetallic greater preparation into lamellar with arrangement according to certain patterns. The higher level of $\mathrm{Al}$ lamellar FeAlis looks increasingly thick and wide. SEM test result indicate the 
presence of aluminum carbides at the grain boundaries of pearlite of $\mathrm{Fe}-\mathrm{Al}-\mathrm{C}$ alloy with $3.3 \%$ up to $9.05 \%$ Al. Interpretation of the results of XRD curves (figur 3) show that there is a ferrite phase.

\section{Corrosion Behavior}

Corrosion testing performed using the technique of polarization in $0.5 \% \mathrm{NaCl}$ solution. Corrosion test result shown in figure 4 and 5. Quantitative value of the metal corroded corrosion rate calculated by the formula as in(1), the unit used is $\mathrm{mm} /$ year.

$$
\begin{aligned}
& R=0,129 \frac{\left(I_{\text {corr }}\right) \cdot E W}{\rho} \ldots \ldots \ldots \ldots \ldots \ldots \ldots \ldots \\
& \text { Where: } \\
& \mathrm{R}=\text { corrosion rate }(\mathrm{mpy}) \\
& I_{\text {corr }} \quad=\text { current density }\left(\mu \mathrm{A} / \mathrm{cm}^{2}\right) \\
& \rho \quad=\operatorname{density}\left(\mathrm{gr} / \mathrm{cm}^{3}\right) \\
& \text { EW = equivalent weight (gr/equivalent) } \\
& \mathrm{EW} \quad=1 / N_{E Q} \\
& N_{E Q} \quad=\sum\left[\frac{N_{i} f_{i}}{a_{i}}\right] \\
& n_{i} \quad=\text { valence } \\
& f_{i} \quad=\text { weight fraction } \\
& a_{i} \quad=\text { atomic weight }
\end{aligned}
$$

Corrosion rate of Fe-Al-C Alloy in $0.5 \% \mathrm{NaCl}$ media ranged from 0.091 to 0.147 $\mathrm{mm} /$ year (table 2).Highest corrosion rate at a level is equal to lowest $\mathrm{Al} 0.147 \mathrm{~mm} /$ year. Based on the level of corrosion resistance table Fe-Al-C alloy with Al content of 1.2 and $3.3 \%$ had a corrosion rate of 0.147 and $0.104 \mathrm{~mm} /$ year are included in a good category. In the range of 5.05\% - 9.09\% $\mathrm{Al}$ corrosion rate $\mathrm{Fe}-\mathrm{Al}-\mathrm{C}$ alloy by 0.091 to $0.084 \mathrm{~mm} /$ year included in the category very good. At higher levels of $\mathrm{Al}$ corrosion rate decreased and reached the lowest value in the $\mathrm{Al}$ content of $7.5 \%$ is equal to 0.084 , increased levels of $\mathrm{Al}$ furthermore does cause an increase in the rate of corrosion.

Excellent corrosion resistance of the alloy $\mathrm{Fe}-\mathrm{Al}-\mathrm{C}$ is due to the presence of elements of aluminum in the alloy system. Aluminum elements would form a layer of aluminum oxide. Thin film of aluminum oxide $\left(\mathrm{Al}_{2} \mathrm{O}_{3}\right)$ is formed on the surface due to contact with the alloy containing oxygen environment capable of providing protection against further corrosion process. At a temperature $600^{\circ} \mathrm{C}$ in addition found also found the compound $\mathrm{Al}_{2} \mathrm{O}_{3}(\mathrm{FeAl}(1-\mathrm{x})) 2 \mathrm{O} 3$ on the oxidized surface. The corrosion of $\mathrm{Fe}-16 \mathrm{Al}-0,05 \mathrm{C}$ alloy at higher temperatures would be lower due to decrease in number of phase $\mathrm{Fe}_{3} \mathrm{AlC}$ [15]. The ferrite phase $\mathrm{FeAl}$ also contributed to the corrosion of $\mathrm{Fe}-\mathrm{Al}-\mathrm{C}$ alloy [16]. So $\mathrm{Fe}_{3} \mathrm{AlC}$ carbide formation and $\mathrm{FeAl}$ ferrite phase in the alloy system is able to improve the corrosion resistance of the alloy significantly. 

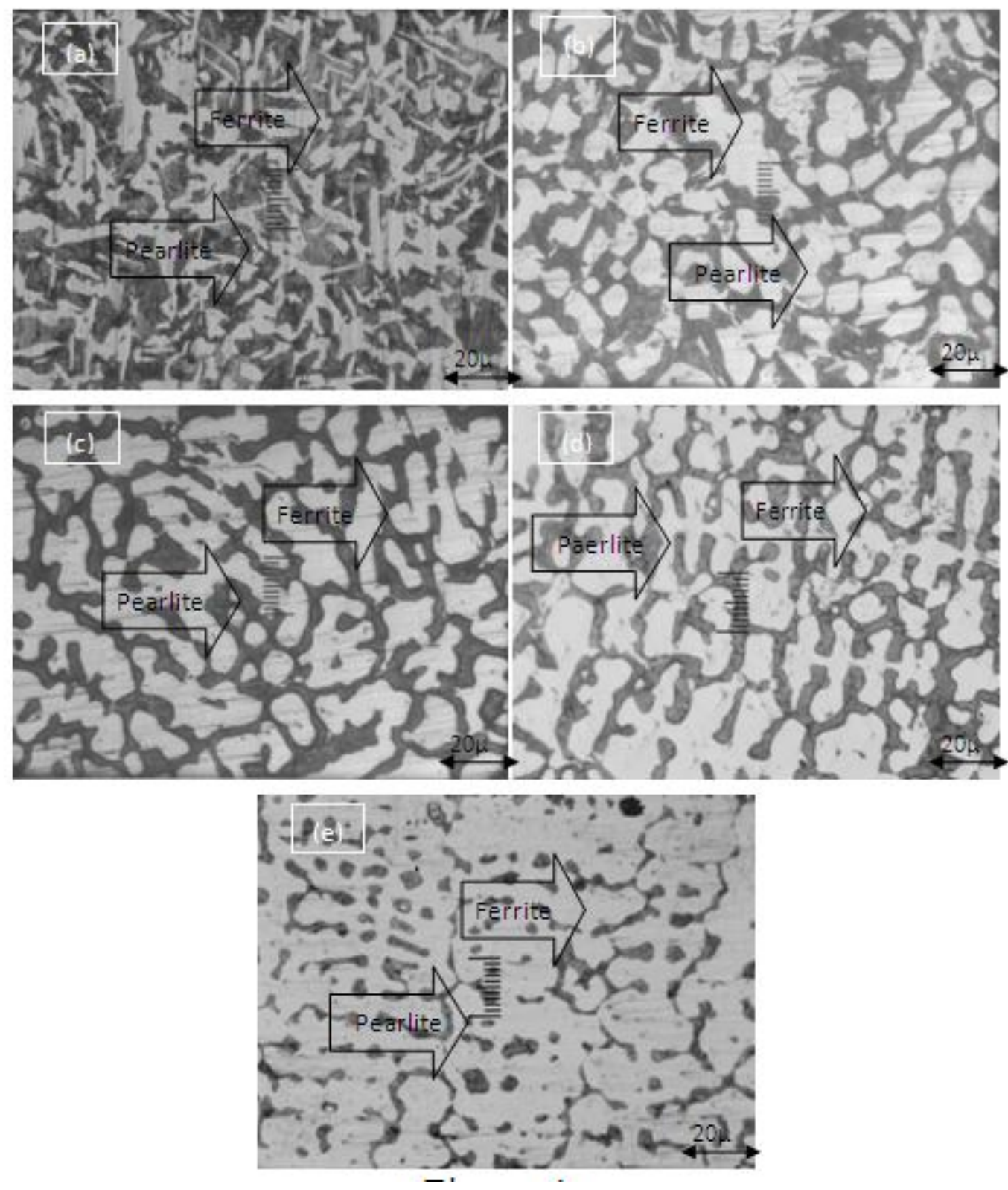

Fig. 1. Microstructure of as cast alloys Fe-Al-C. (a). Fe-1,24Al (b). Fe-3,3Al (c). Fe$5,5 \mathrm{Al}$ (d). Fe-7,5Al (e). Fe-9,05Al 

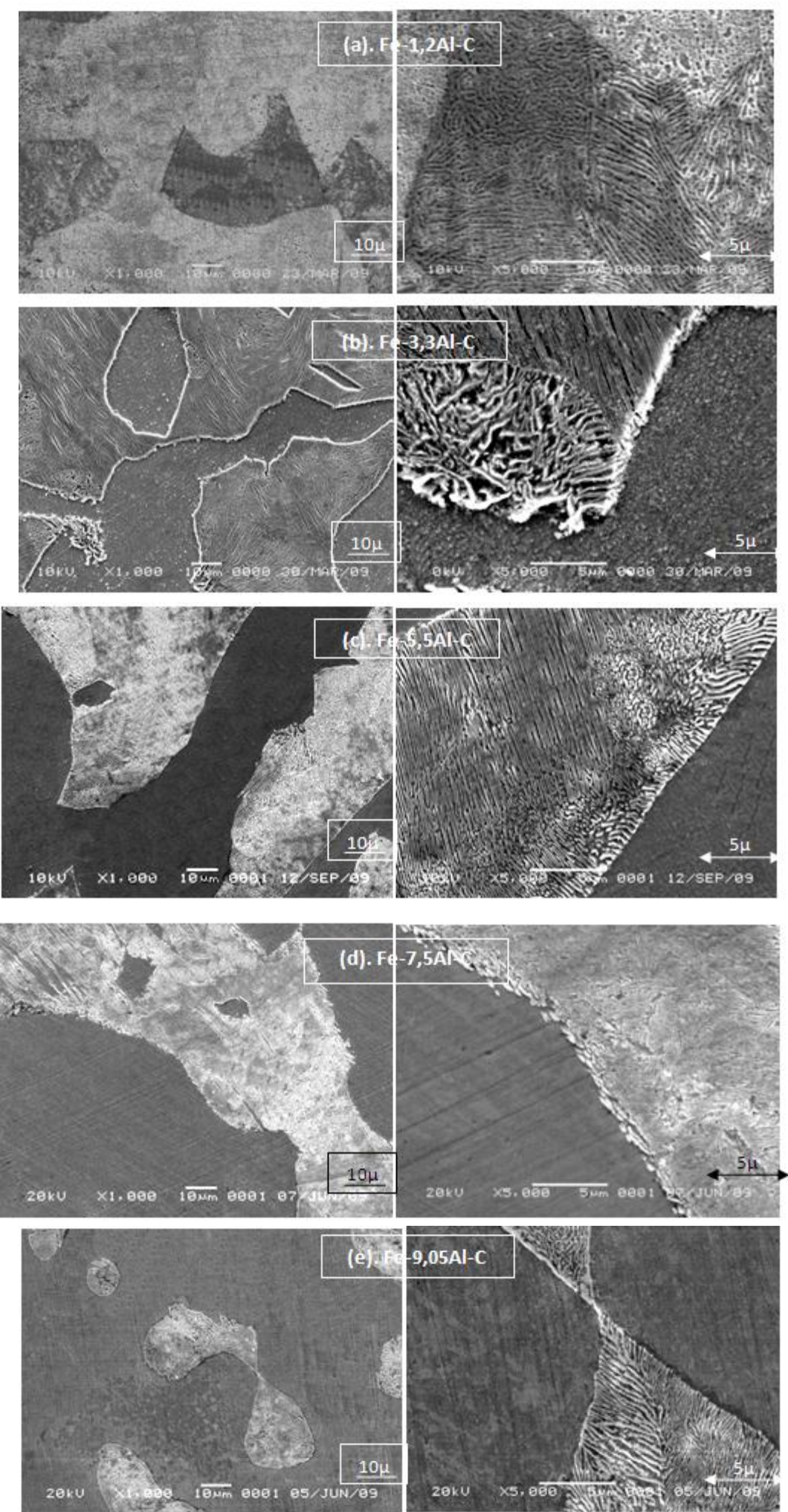

Fig. 2. Micrograph (SEM) microstructure of as cast alloys Fe-Al-C 


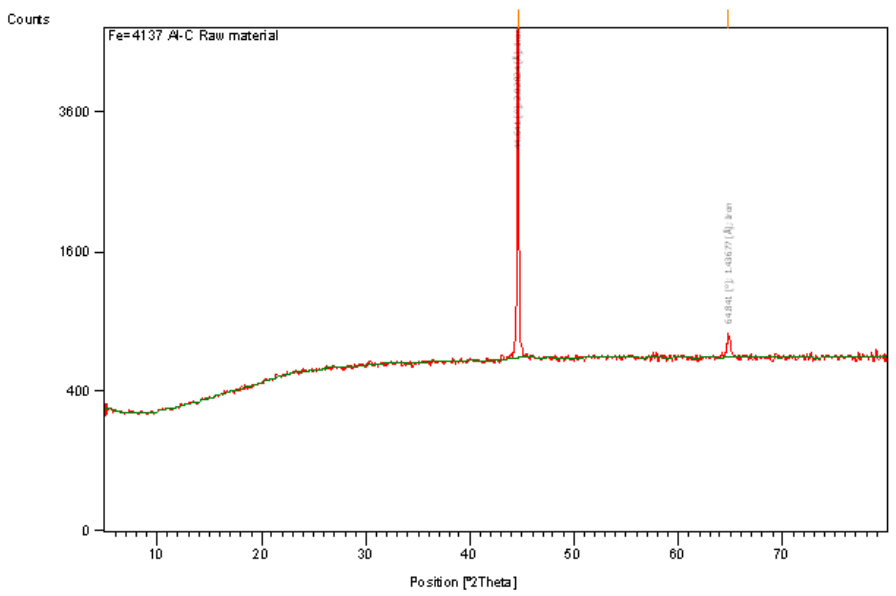

Fig. 3. XRD pattern of Fe-Al-C alloy

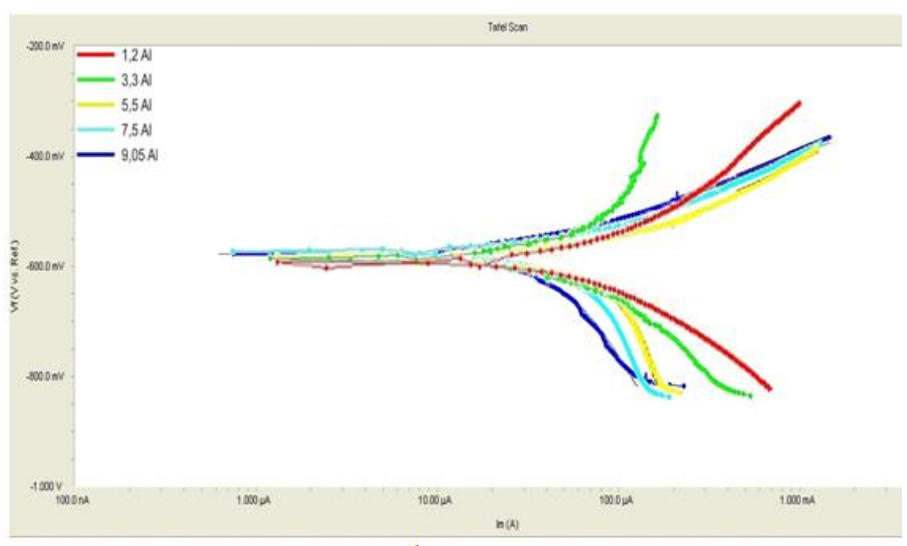

Fig. 4. Polarization curve of Fe-Al-C alloy

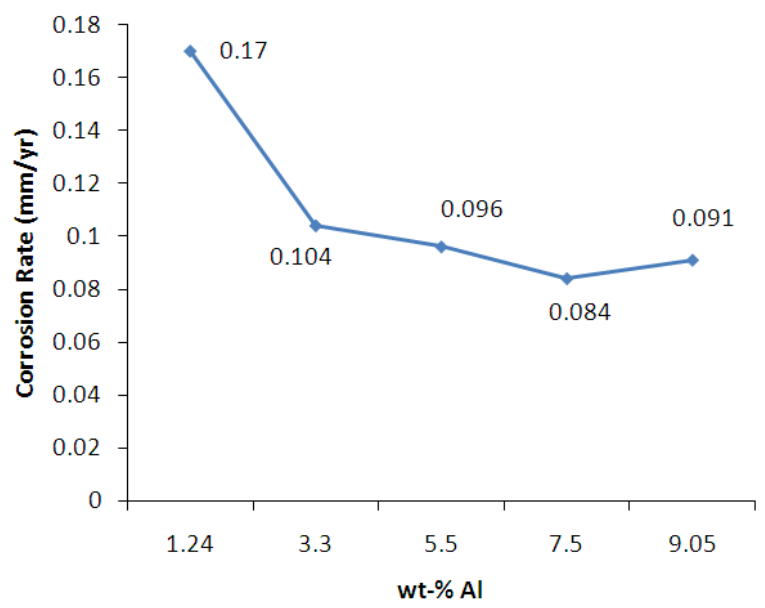

Fig.5. Corrosion rate of Fe-Al-C alloy 
Table 1. Chemical composition alloys, wt-\%

\begin{tabular}{cccccc}
\hline Alloy/lement & A & B & C & D & E \\
\hline Fe & Bal. & Bal. & Bal. & Bal. & Bal. \\
$\mathrm{Al}$ & 1.24 & 3.30 & 5.50 & 7.50 & 9.05 \\
$\mathrm{C}$ & 0.55 & 0.54 & 0.55 & 0.56 & 0.56 \\
$\mathrm{Mn}$ & 0.62 & 0.63 & 0.62 & 0.64 & 0.64 \\
$\mathrm{P}$ & 0.02 & 0.02 & 0.03 & 0.03 & 0.03 \\
$\mathrm{~S}$ & 0.03 & 0.03 & 0.02 & 0.03 & 0.03 \\
$\mathrm{Si}$ & 0.62 & 0.62 & 0.63 & 0.61 & 0.62 \\
$\mathrm{Sn}$ & 0.01 & 0.01 & 0.01 & 0.01 & 0.01 \\
\hline
\end{tabular}

Table 2. Corrosion parameters of Fe-Al-C alloy

\begin{tabular}{ccccccc}
\hline Alloys & $\begin{array}{c}\mathrm{I} \text { corr } \\
\left(\mu \mathrm{A} / \mathrm{cm}^{2}\right)\end{array}$ & $\begin{array}{c}\text { Ecorr } \\
(\mathrm{mV})\end{array}$ & EW & $\begin{array}{c}\mathrm{D} \\
\left(\mathrm{g} / \mathrm{cm}^{3}\right)\end{array}$ & $\begin{array}{c}\mathrm{CR} \\
(\mathrm{mpy})\end{array}$ & $\begin{array}{c}\mathrm{CR} \\
(\mathrm{mm} / \mathrm{yr})\end{array}$ \\
\hline $\mathrm{Fe}-1.2 \mathrm{Al}-\mathrm{C}$ & 18.5 & -597 & 18.76 & 7.69 & 5.82 & 0.147 \\
$\mathrm{Fe}-3.3 \mathrm{Al}-\mathrm{C}$ & 13.2 & -580 & 18.18 & 7.54 & 4.11 & 0.104 \\
$\mathrm{Fe}-5.5 \mathrm{Al}-\mathrm{C}$ & 12.0 & -577 & 17.86 & 7.25 & 3.81 & 0.096 \\
$\mathrm{Fe}-7.5 \mathrm{Al}-\mathrm{C}$ & 10.4 & -562 & 17.54 & 7.10 & 3.31 & 0.084 \\
$\mathrm{Fe}-9.05 \mathrm{Al}-\mathrm{C}$ & 11.2 & -571 & 17.24 & 6.90 & 3.61 & 0.091 \\
\hline
\end{tabular}

\section{Conclusion}

Microstructure of Fe-Al-C alloy is ferrite and pearlite where the higher levels of $\mathrm{Al}$ ferrite phase increasingly dominant. Corrosion rate of $\mathrm{Fe}-\mathrm{Al}-\mathrm{C}$ alloy ranged from 0.084 to 0.047 , where the higher levels of $\mathrm{Al}$ corrosion rate decreases until it reach the lowest price on the $\mathrm{Al}$ content of $7.5 \%$.

\section{Acknowledgements}

The authors are pleased to acknowledge the financial support of this research by the "Hibah Bersaing" Program, Direktorat Jendral Pendidikan Tinggi, Kementerian Pendidikandan Kebudayaan, Republic of Indonesia.

\section{References}

[1] Shackelford, J.F., 1992, Introduction to Material Science for Engineers, 3th ed., McMillan Publishing Company, New York.

[2] Kim, H., Suh, D.W., and Kim, N.J., 2013, Fe-Al-Mn-C lightweight structural alloys: a review on the microstructures and mechanical properties, Scienceand Technologyof Advance Materials.Vol.14 No.1

[3] Frommeyer, 2000, Physical Mechanical PropertiesIron-Aluminum-(Mn-Si) Lightweight Steels, The 1999 ATS International Steelmaking Conference, 
Paris. Sec.4.

[4] Huang, B.X., Wang, X.D., Rong, Y.H., Wang, L., and Jin, L., 2006, Mechanical behavior and martensitic transformation of an $\mathrm{Fe}-\mathrm{Mn}-\mathrm{Si}-\mathrm{Al}-\mathrm{Nb}$ alloy, Materials Science Engineering A 438-440 p. 306-311

[5] Kobayashi, S., Zaefferer, S., Schneider, A., Raabe, D., danFrommeyer, G., 2005, Optimisation of Precipitation for Controlling Recrystallization of Wrought Fe3Al Based Alloys, Intermetallics, 13, 1296-1303.

[6] Jablonska, M., Jasik, A., danHanc, A., 2009, Structures and Phases transitions of The Alloys on the bases of $\mathrm{Fe}-\mathrm{Al}$ Intermetallic Phases, International Scientific Journal vol. 29. Issue 1, p.16-19.

[7] Baligidad, R.G., Prakash, U., Ramakrishna Rao, V., Rao, P.K., danBallal N.B., 1996, Effect of Carbon Content on Mechanical Properties of ElectroslagRemelted Fe3Al Based Intermetallic alloys, ISIJ, Vol. 36, No. 12, 1453-1458.

[8] Baligidad, R.G., Prakash, U., danRadha Krishna, 1998, Effect of Carbon Addition on Structure and Mechanical Properties of ElectroslagRemelted Fe0wt.\% Al alloy, Vol. 249, No. 1-2, 97-102.

[9] Baligidad, R.G., danSatya Prasad, K./2007, Effect of Al and C on Structure And Mechanical Properties of Fe-Al-C alloys, Materials Science And Technology, vol 23, no. 1, p 38-44.

[10] Parker, S.H.F., Grundy, P.J., Jones, G.A., Briggs, I. dan Clegg, A.G., 1988, Micro structural and Magnetic Properties of the Permanent Magnet Material Fe-Al-C, Journal of Material Science, Vol. 23, Hal. : 217-222.

[11] Kao, C.H., dan Wan C.M., 1988, Effect of Manganese on the oxidation of FeMn-Al-CAlloys, Journal of Materials Science, Vol. 23, Hal.: 744-752.

[12] Giza, K., Bala, H., Wysocki, J.J., and Szymura, S., 1999, Corrosion Resistance of Fe-Al-C Permanent Magnet Alloy, Intermetallic, Vol.6, issue 5, p.357-362.

[13] Chao, Y.C., and Liu, C.H., 2002, Effect of Mn Content on the Microstructure and Mechanical Properties of Fe-10Al-xMn-1.0C Alloy, Materials Transactions, Vol. 3, No. 10, pp. 2635-2642.

[14] Honeycombe, R.W.K. danBhadeshia, H.K.D., 1995, Steel Microstructure and Properties, $2^{\text {nd }}$ ed., Edward Arnold, London.

[15] Shankar Rao, V., 2004, High Temperature Oxidation Behavior of Fe-Al-C alloys : an Overview, Materials Science and Engineering. A, Vol. 364, No. 12, pp 232-239.

[16] Tjong, S.C., 1986, Stress Corrosion Cracking behavior of the duplex Fe-10Al$29 \mathrm{Mn}-0,4 \mathrm{C}$ alloy in $20 \% \mathrm{NaCl}$ solution at $100^{\circ} \mathrm{C}$, Journal of Material Science, Vol. 21, Hal.: 1166-1170. 
